\title{
Potential of C-Band Multi-polarized and Polarimetric SAR Data for Soil Drainage Classification and Mapping
}

\author{
Mohamed A. Niang ${ }^{1}$, Michel C. Nolin ${ }^{1}$ and Monique Bernier ${ }^{2}$ \\ 1 Pedology and Precision Agriculture Laboratories, Agriculture and Agri-Food Canada \\ 2Institut National de la Recherche Scientifique, Eau-Terre-Environnement (INRS-ETE)
}

Québec (Canada)

\section{Introduction}

Routine soil surveys determine many soil properties but soil drainage and soil moisture indicators (soil permeability, hydrologic soil group, etc.) are often the most relevant for agro-environmental purposes. They influence in-field crop yield and affect several environmental processes, i.e., soil erosion, nutrient and pesticide transport by runoff water and leaching, nitrification, and greenhouse gas production. Up-to-date information is needed to guide watershed and site-specific crop management but conventional soil survey procedures are time-consuming and expensive. New technologies, such as remote and proximal sensing, feature in many key soil science applications and are particularly effective for mapping soil drainage (Niang et al., 2007 and 2006; Bell et al., 1994 and 1992; Lee et al., 1988; Levine et al., 1994; Cialella et al., 1997; Campling et al., 2002; Liu et al., 2008). Since soil drainage is often related to other properties, such as soil water content and texture (Kravchenko et al., 2002), it can be mapped using both optical and radar remote sensing. When cloud-free optical imagery is not available, radar imaging is the best option. For most soil conditions, soil surface moisture and vegetative growth and development are considered to be indicators of soil drainage. However, these factors also affect radar backscatter. Knowledge of soil and crop types is needed to understand the relationship between radar backscatter and soil drainage (Smith et al., 2006). Soil drainage is a dynamic process that can by defined only by integrating several factors: water-holding capacity, hydraulic conductivity, and seasonal variation in water-table depth (Jennifer et al., 2001). Thus, radar remote sensing data must be acquired under appropriate environmental conditions to effectively determine soil drainage classes. Most studies on agricultural applications of radar remote sensing involve single frequency and single polarization data. Unless such data are combined in multi-temporal series, they are limited to a few values (McNairn and Brisco, 2004). Only a few studies suggest that multi-polarization radar could provide valuable and timely information by delineating homogenous soil zones (McNairn and Brisco, 2004; van der Sanden, 2004). One recent study showed that soil drainage could be mapped on an in-field scale by using high-resolution optical and C-band SAR data from 
CV-580 (Liu et al., 2008). However, the relationship between polarimetric parameters and soil drainage indicators was not investigated.

This chapter evaluates the feasibility of using multi-polarization and polarimetric C-band SAR data from CV-580 to determine soil drainage classes. First, a Wishart supervised classification was applied to determine land use. Multi-polarized channels $(\mathrm{HH}, \mathrm{VH}, \mathrm{VV}$, RR, RL LL, $\psi 45^{\circ}$, and $\psi 135^{\circ}$ ) were synthesized and backscattering coefficients were derived for the reference soil profile pits acquired from the soil survey. These data were analysed for designated land use and drainage classes. Polarimetric parameters from the Cloude and Pottier (1997) decomposition were also analysed. Linear discriminant analysis was applied on each land use using soil drainage classes from soil survey. The feasibility of using this approach with RADARSAT-2 data to map soil drainage is discussed.

\section{Materials and methods}

The study area was located at the Bras d'Henri watershed $\left(167 \mathrm{~km}^{2}\right)$ near Quebec City (Figure 1). During the summers of 2004 and 2005, intensive soil surveys were conducted over the entire watershed at two prospecting scales (1:20,000 and 1:40,000). A total of 1612 soil profiles were collected for updating and upgrading the soil map and a recommended sampling method based on random transects (Nolin et al., 1994) was adopted. Five out of seven soil drainage classes, ranging from well-drained to very-poorly drained, were identified in the watershed according to the soil surveyor's expert knowledge. These data were used as a validation dataset. Polarimetric C-band SAR data from CV-580 were acquired in November 2005 over the study area. An area of $101 \mathrm{~km}^{2}$, with 1045 soil profiles, was covered (Table 1). The SAR data were radiometrically calibrated by the Canadian Center of Remote Sensing (Murnaghan, 2005). Radiometric accuracy was less than $1 \mathrm{~dB}$ for the four polarizations. Slant range resolution was $4 \times 4 \mathrm{~m}$ (azimuth $\times$ range) for the SIR-C product and incidence angles were large $\left(33^{\circ}\right.$ to $\left.67^{\circ}\right)$.

The polarizations $\left(\mathrm{HH}, \mathrm{HV}, \mathrm{VV}, \mathrm{RR}, \mathrm{LL}, \psi 45^{\circ}\right.$, and $\left.\psi 135^{\circ}\right)$ were synthesized from the SAR data using Polarimetric WorkStation software (Touzi and Charbonneau, 2004). These polarizations were used as ancillary data for soil drainage classification. The assumption was that, under given soil moisture conditions, variation in the radar backscatter would indicate soil drainage states. This relationship between polarizations and soil moisture has been documented (Baronti et al., 1995). Linear cross-polarizations (HH, VV, and HV) refer to the power from the transmitted linear wave $(\mathrm{H}$ or $\mathrm{V})$ recorded by the sensor and repolarized into the orthogonal polarizations $(\mathrm{V}$ or $\mathrm{H})$. With fully polarimetric data, nonlinear polarizations, such as circular and elliptical polarizations, can be synthesized.

For the left-handed circular waves (L), the electric field vector rotates counter-clockwise; for the right-handed circular waves $(\mathrm{R})$, the vector rotates clockwise. The responses of circular co-polarizations (RR and LL) are associated with the volume or multiple scattering and the handedness of received wave, while the cross-polarization (RL) is associated with smooth surfaces (McNairn et al., 2002). Elliptical polarizations can also be derived from polarimetric data by defining the orientation $(\psi)$ and ellipticity $(\chi)$ angles. The two polarizations $\left(\psi 45^{\circ}\right.$ and $\left.\psi 135^{\circ}\right)$ used in this study correspond at $\chi=0^{\circ}$ and $\psi=45^{\circ}$, and $\chi=0^{\circ}$ and $\psi 135^{\circ}$, respectively, and were positively correlated to soil moisture (McNairn et al., 2002). 
Another unique feature provided by the fully polarimetric data is the possibility of separating different scattering distributions by sub-matrices associated with the specific scattering properties of point, or distributed scatters and their ensembles. Several polarimetric target decomposition theorems have been proposed, including: coherent (Krogager, 1992; Cameron and Leung, 1990), non-coherent (Huynen, 1965; Holm and Barnes, 1988), model-based decomposition (Freeman and Durden, 1998), eigenvector-based decomposition (van Zyl, 1989; Cloude, 1992), and others as critically associated in the literature (Cloude, 1992; Cloude and Pottier, 1996 and 1997).

The H/A/ $\underline{\text { a }}$ (entropy H, anisotropy A, and mean alpha angle $\underline{\alpha}$ ) decomposition theorem proposed by Cloude and Pottier (1997) was used in this study to determine soil drainage classes. This decomposition is based on eigenvalues extracted from the coherency matrix. The average target scattering matrix estimated with these parameters allows the surface roughness to be separated from the soil dielectric constant (Hajnesk et al., 2001), which depends linearly on soil moisture.

For an accurate extraction of the radar backscatter, a $5 \times 5$ Lee filter window (Lee, 1986) was applied to reduce the speckle noise. The Wishart supervised classification (H/A/ $\underline{a})$ was also applied to the SAR data to assess the characterization of soil drainage classes for agricultural areas. The training areas were designated on a RGB composite color and the classification was performed with three scattering mechanisms (single bounce scattering, double bounce scattering, and volume diffusion) derived from the Freeman decomposition.

A principal component analysis (PCA) was used to reduce the effects of collinear data and matrix dimensions. The contribution of synthetized polarization and polarimetric parameters on soil drainage classification was assessed by forward stepwise discriminant analysis.

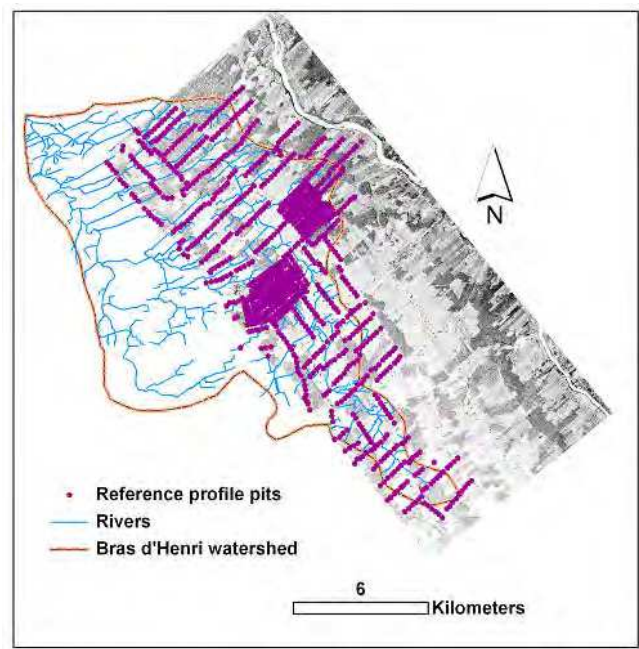

Fig. 1. Study area: The Bras d'Henri watershed (QC, Canada) superimposed with the CV-580 SAR; geo-referenced soil profile pits labelled as points (.) represent the training / validation dataset 


\begin{tabular}{||l|r|r||}
\hline \hline Drainage class & Count & \multicolumn{1}{|c|}{$\%$} \\
\hline D3 & 53 & 5.1 \\
\hline D4 & 71 & 6.8 \\
\hline D5 & 303 & 29.0 \\
\hline D6 & 495 & 47.4 \\
\hline D7 & 123 & 11.8 \\
\hline Total & 1045 & 100.0 \\
\hline
\end{tabular}

Table 1. Distribution of soil profile pits by drainage classes

\section{Results and discussion}

Figure 2 shows the meteorological conditions during November 2005. Two days before the CV-580 overpass, cumulative precipitation for November was about $30 \mathrm{~mm}$ and mean air temperature was about $5^{\circ} \mathrm{C}$. These conditions can cause water saturation on certain soil types; soil water infiltration capability and drainage states could be shown after these dates.

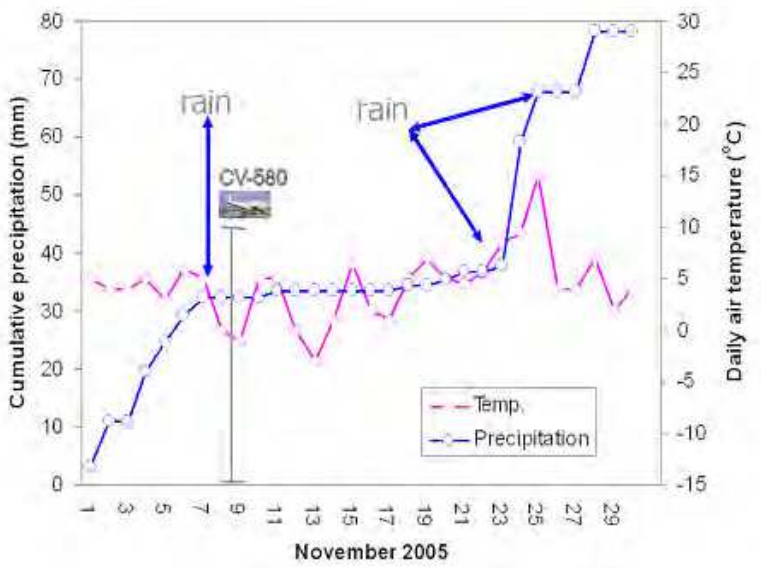

Fig. 2. Meteorological conditions during the acquisition of CV-580 SAR data

Figure 3 shows the Pauli color-coded image of part of the watershed which consists of agricultural areas, forest, wetland, and urban zones. It was obtained by assigning the red color $\mathrm{R}=|\mathrm{HH}-\mathrm{VV}|$, green color $\mathrm{G}=|\mathrm{HV}|$, and blue color $\mathrm{B}=|\mathrm{HH}+\mathrm{VV}|$, respectively. The Freeman decomposition using $R=\left|P_{D B}\right|, G=\left|P_{v}\right|$, and $B=\left|P_{S}\right|$ for red, green, and blue is presented in Figure 4 . The $P_{\mathrm{DB}}, \mathrm{P}_{\mathrm{v}}$, and $\mathrm{P}_{\mathrm{s}}$ parameters are powers scattered by the doublebounce, volume, and surface components of their covariance matrices, respectively. The Freeman decomposition uses similar characteristics as the Pauli-based decomposition, but provides a more realistic representation because scattering models are used for dielectric surfaces. 


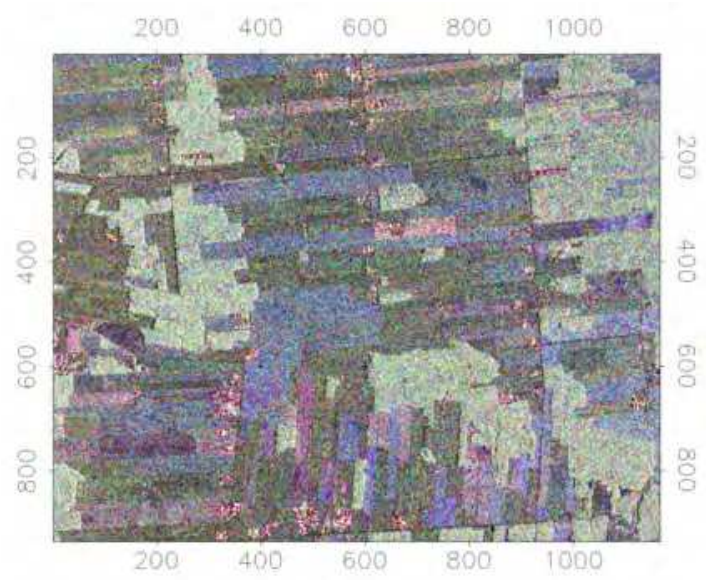

Fig. 3. Image obtained using the Pauli decomposition with $R=|H H-V V|, G=|H V|$, $\mathrm{B}=|\mathrm{HH}+\mathrm{VV}|$

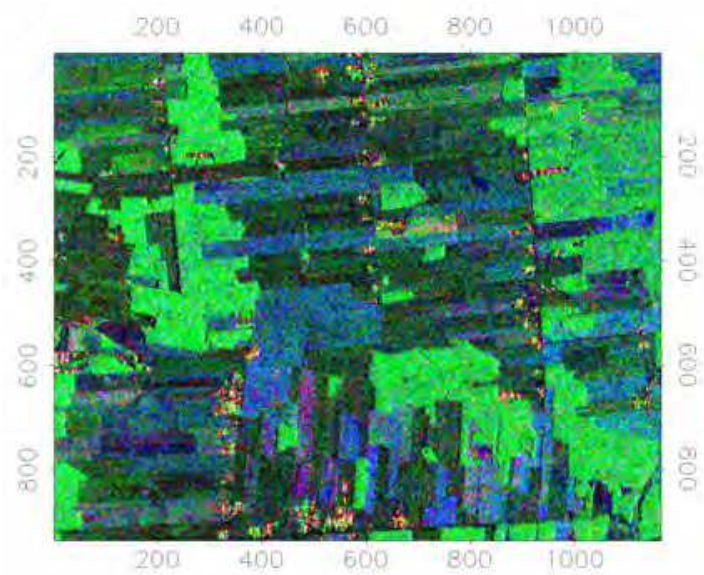

Fig. 4. Image obtained using the Freeman decomposition with $R=\left|P_{D B}\right|, G=\left|P_{V}\right|$, and $B=\left|P_{S}\right|$

Two types of agricultural areas, with $\mathrm{P}_{\mathrm{s}}$ (blue) the predominant scattering mechanism and dark areas, appear to have the same contribution from the three scattering mechanisms in Figure 4. Some training areas were designated in these areas for the Wishart supervised classification $(\mathrm{H} / \mathrm{A} / \underline{\mathrm{a}})$. This study focused on these agricultural areas.

Classification results are given in Figure 5. The overall classification accuracy was $86 \%$. Urban areas had a lower classification accuracy (63\%) but the two designated agricultural areas had good classification accuracy: 86\% for agricultural Area 1 and $93 \%$ for agricultural Area 2. 


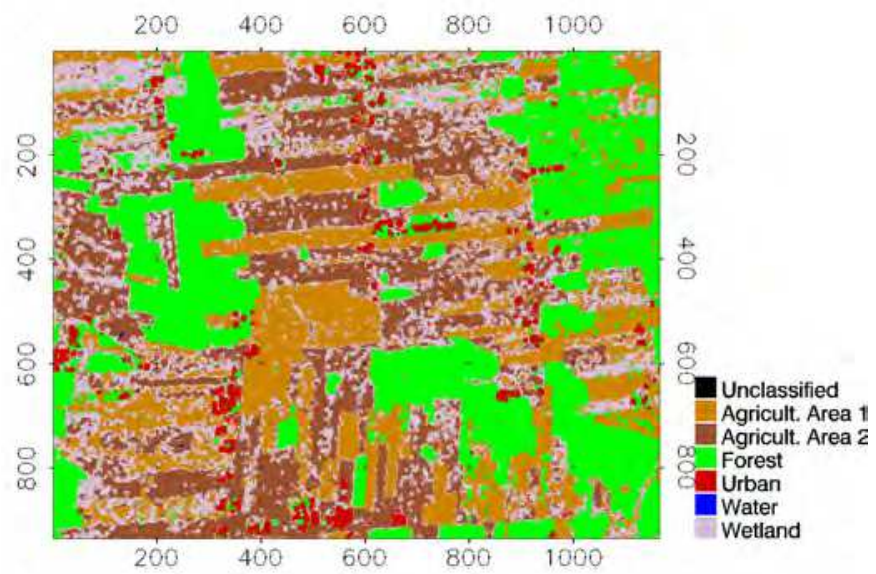

Fig. 5. Wishart supervised classification $(\mathrm{H} / \mathrm{A} / \underline{\mathrm{q}})$

\begin{tabular}{||l|r|r|r|r|r|r||}
\hline \multicolumn{1}{|c|}{ Land use } & Forest & $\begin{array}{c}\text { Agricultural } \\
\text { Area 1 }\end{array}$ & $\begin{array}{c}\text { Agricultural } \\
\text { Area 2 }\end{array}$ & Water & Wetland & Urban \\
\hline Forest & 90 & 1 & 3 & 0 & 0 & 5 \\
\hline Agricultural Area 1 & 2 & 86 & 2 & 0 & 0 & 10 \\
\hline Agricultural Area 2 & 6 & 0 & 93 & 0 & 0 & 1 \\
\hline Water & 0 & 0 & 5 & 91 & 0 & 2 \\
\hline Wetland & 1 & 4 & 2 & 1 & 91 & 1 \\
\hline Urban & 7 & 23 & 7 & 0 & 0 & 63 \\
\hline
\end{tabular}

Table 2. Confusion matrix (\%). Rows represent user-defined groups while columns represent segmented clusters

\subsection{Multi-polarization analysis}

The relationship between the mean backscattering with soil drainage classes and synthesized polarizations is given in Figures 6 and 7 for the two designated agricultural areas. An increase of the backscattering signal is observed for these areas, and for all polarizations, as a function of soil moisture as depicted by theoretical models IEM (Fung, 1994), SPM and GO (Ulaby et al., 1986), and soil drainage classes. For the agricultural Area 1 , there are significant differences (about $4 \mathrm{~dB}$ ) between well-drained (D3+D4) and poorlydrained soil classes (D5+D6) (Figure 6). Unfortunately, there were no data for the very poorly-drained soil class (D7). For the agricultural Area 2, three sets of drainage classes can be distinguished: D3, D4+D5+D6, and D7. The VV backscatter is slightly greater than the $\mathrm{HH}$ polarization for the two areas. According to Dobson and Ulaby (1986), this result may be due to the high incidence angle $\left(33^{\circ}\right.$ to $\left.66^{\circ}\right)$ of acquisition for the SAR image. Therefore, differences in the mean backscattering signal behaviour for the first three soil drainage classes in the two agricultural areas indicate that scattering mechanisms differ among these fields. Meteorological conditions prevailed until the date of harvest and, therefore, land cover was highly variable: ploughed fields (forage, cereal, soybean, or harvested corn), 
harvested but not ploughed fields with crop residue, and unharvested corn fields. In this context, polarimetric parameters may be useful for analysing the physical properties (dielectric and geometric) of the two agricultural fields.

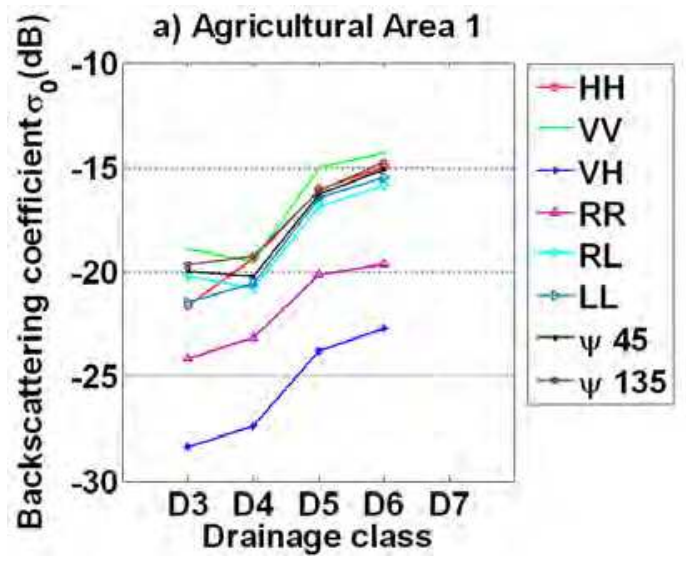

Fig. 6. Relationship of the backscattering coefficient with drainage classes in agricultural Area 1 for the polarizations

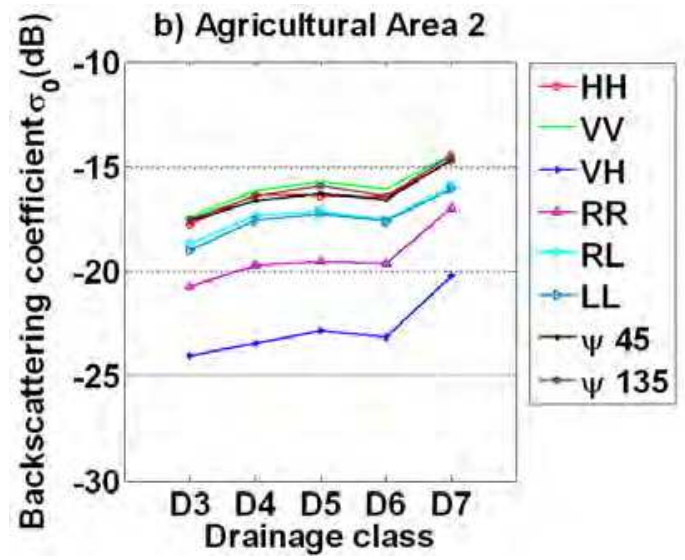

Fig. 7. Relationship of the backscattering coefficient with soil drainage classes in agricultural Area 2 for the polarizations

\subsection{Polarimetric analysis}

Figures 8,9 , and 10 give the $\underline{\alpha}, \mathrm{H}$, and A parameters extracted from the $3 \times 3$ coherency matrix, respectively. The $\underline{a}$ is the main parameter used to identify the dominant scattering mechanism. Entropy, $\mathrm{H}$, is a statistical descriptor of the randomness of the scattering process which can be interpreted as the degree of statistical disorder. Anisotropy, A, measures the relative importance of the second and the third eigenvalues. It is a complementary parameter to entropy and can be used as a discriminating index when $\mathrm{H}>0.7$. 


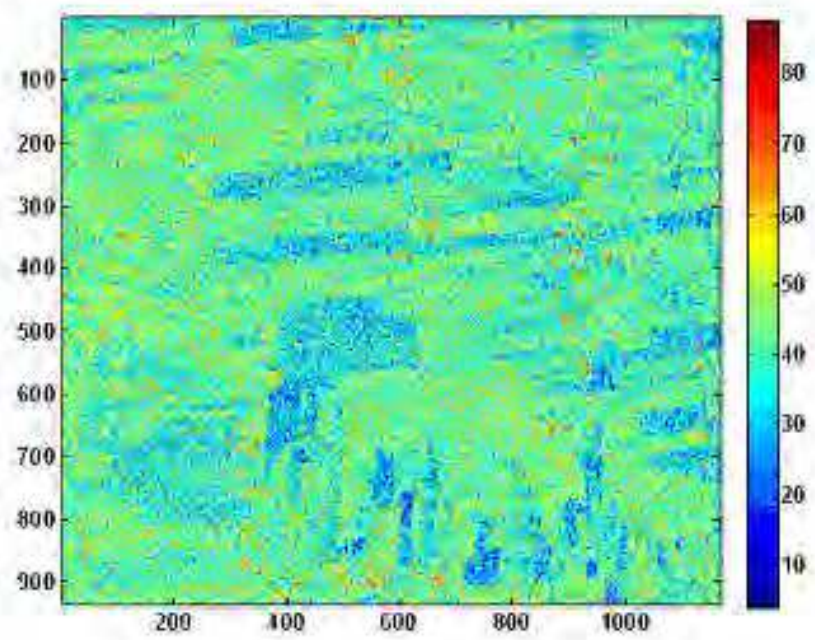

Fig. 8. Map showing the variation of the parameter, $\underline{\mathrm{a}}\left({ }^{\circ}\right)$

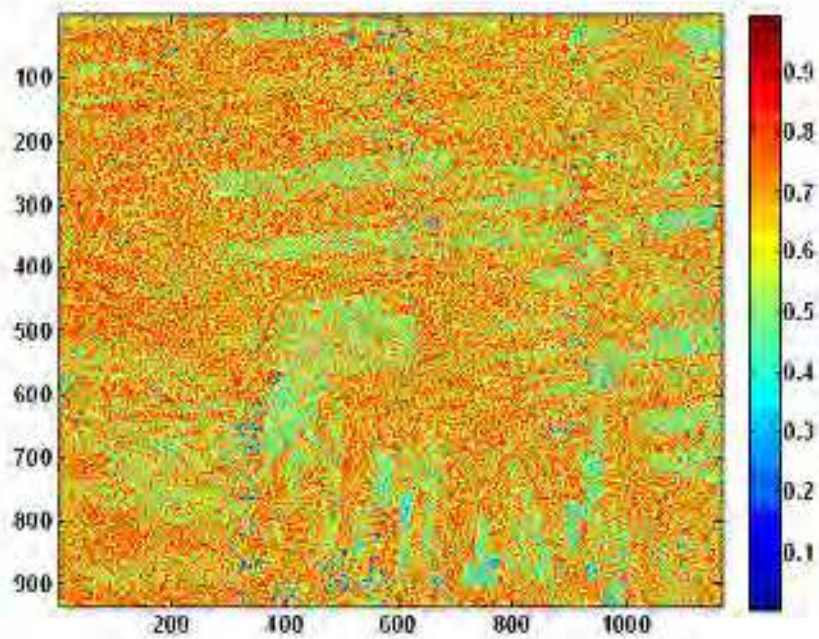

Fig. 9. Map showing the variation of the entropy parameter, $\mathrm{H}$ 


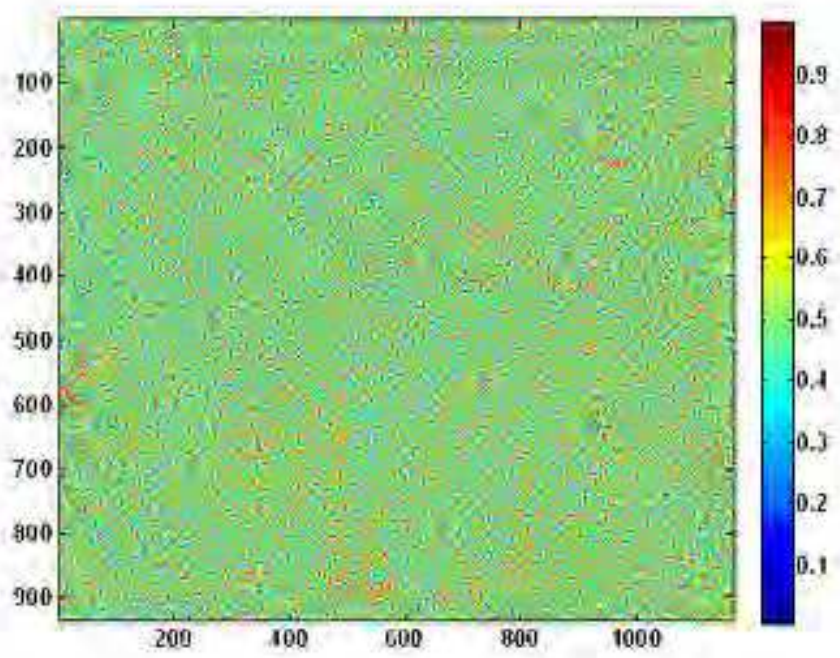

Fig. 10. Map showing the variation of the anisotropy parameter, A

The relationship of these parameters with the soil drainage classes for the two agricultural areas is given in Figures 11 and 12. The low values of the $\underline{a}$ parameter $\left(15^{\circ} \leq \underline{a} \leq 31^{\circ}\right)$ for the two agricultural areas suggest that the scattering corresponds to the single-bounce scattering produced by the rough surface. Therefore, the low values of the entropy $(0.05 \leq \mathrm{H}$ $\leq 0.1$ ) for agricultural Area 1 indicate that the scattering process corresponds to a pure target. For agricultural Area 2, the values $(0.05 \leq \mathrm{H} \leq 0.2)$ indicate the presence of other scattering mechanisms weighted by the corresponding eigenvalues $\left(\lambda_{1}, \lambda_{2}, \lambda_{3}\right)$. The values of the anisotropy were greater $(\mathrm{A} \geq 0.6)$ in the agricultural Area 2 for all drainage classes, whereas in the agricultural Area 1, the A parameter was in the medium range. This result confirms the presence of two scattering mechanisms with a dominant process and a secondary one with medium probability $\left(\lambda_{3} \approx 0\right)$. In agreement with the Freeman decomposition (Figure 4), we conclude that the agricultural Area 1 was composed mostly of bare soils while the agricultural Area 2 consisted of less dense harvested fields with short plants. Under conditions similar to those of agricultural Area 1, the combination of $\underline{a}$ and $\mathrm{H}$ parameters appears to be sufficient for identifying soil drainage classes (Figure 11). 

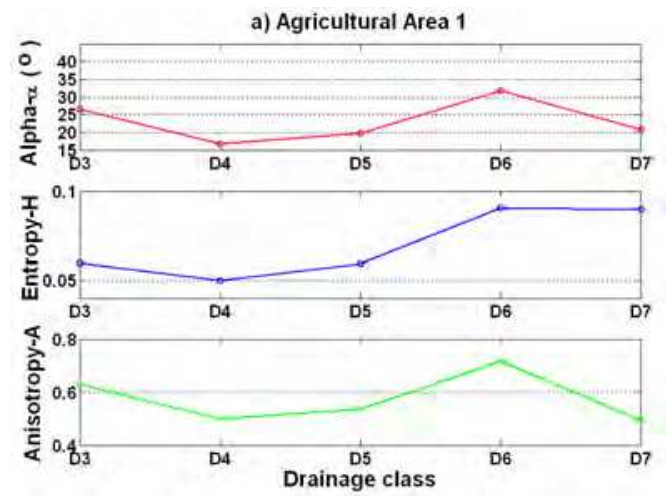

Fig. 11. Relationship of parameters $\underline{\alpha}, \mathrm{H}$, and A with soil drainage classes in the agricultural Area 1
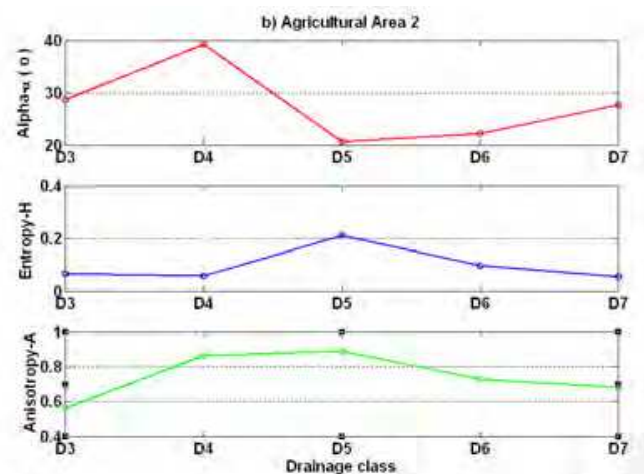

Fig. 12. Relationship of parameters $\underline{\alpha}, \mathrm{H}$, and A with soil drainage classes in agricultural Area 2

\subsection{Discriminant analysis}

In an approach to reduce collinearity, a principal component analysis (PCA) was applied on the multi-polarization dataset. The first two components, consisting of $94 \%$ of total variance of the information from the multi-polarization dataset, were selected for further analyses. The contribution of the multi-polarization data and the polarimetric parameters was studied using the following discriminant analysis criteria: Wilks' lambda, $\mathrm{F}$ to remove, significant level associated to the partial Lambda, and the tolerance (Table 3).

The multivariate solution shows that the two PCA factors (PC1 for the agricultural Area 1, and PC2 for the agricultural Area 2) extracted from the multi-polarization dataset were the principal discriminators for soil drainage classes with a p-level near 0 and good tolerance. Anisotropy was the polarimetric parameter that had the most significant contribution to the discriminant function with good tolerance. The two other polarimetric parameters ( $\underline{\mathrm{a}}$ and $\mathrm{H})$ contributed to the classification model but their tolerance was weak. 


\begin{tabular}{||l|c|c|c|c||}
\hline Variables & Wilks' $\boldsymbol{\lambda}$ & F to remove & p-level & Tolerance \\
\hline$\underline{\mathrm{a}}$ & 0.91 & 1.81 & 0.13 & 0.25 \\
\hline $\mathrm{A}$ & 0.91 & 2.32 & 0.06 & 0.89 \\
\hline $\mathrm{H}$ & 0.91 & 1.86 & 0.12 & 0.24 \\
\hline PCA 1 & 0.95 & 14.19 & 0.00 & 0.99 \\
\hline PCA2 & 0.92 & 5.9 & 0.00 & 0.91 \\
\hline
\end{tabular}

Table 3. Contribution of the selected parameters to the model classification

The results of the classification by discriminant analysis are presented in Table 4. For the two agricultural areas, poorly-drained soils (D6) were clearly identified (73-97\%). Imperfectly-drained soils (D5) were detected in the agricultural Area 1 with an overall classification accuracy of $63 \%$. The well-drained class (D3) was detected with an overall classification accuracy of only $33 \%$. The meteorological conditions which prevailed during the acquisition of polarimetric SAR data, and the small proportional size of soil drainage classes in the agricultural areas, can partially explain the relatively low performance of the classification by discriminant analysis.

\begin{tabular}{||c|c|c|c|c||}
\hline \hline \multirow{2}{*}{$\begin{array}{c}\text { Drainage } \\
\text { class }\end{array}$} & \multicolumn{2}{|c|}{ Agricultural Area 1 } & \multicolumn{2}{c||}{ Agricultural Area 2 } \\
\cline { 2 - 5 } & Proportion & Percent correct & Proportion & Percent correct \\
\hline D3 & 0.13 & 33.3 & 0.06 & 0.0 \\
\hline D4 & 0.04 & 0.0 & 0.07 & 0.0 \\
\hline D5 & 0.35 & 62.5 & 0.30 & 2.4 \\
\hline D6 & 0.48 & 72.7 & 0.48 & 96.7 \\
\hline D7 & 0.00 & 0.0 & 0.09 & 19.2 \\
\hline Total & 1.00 & 60.9 & 1.00 & 49.4 \\
\hline \hline
\end{tabular}

Table 4. Mean alpha, anisotropy, and entropy by drainage class for two agricultural areas

\section{Conclusion}

This research demonstrates the feasibility of using multi-polarization and polarimetric data for soil drainage classification and mapping. The new generation of SAR technology, with its high spatial resolution of fully polarimetric SAR data from RADARSAT-2, could help to clarify the complex relationship between soil drainage and radar backscatter and subsequently be a resource for developing operational models. Because of the dynamic changes of soil drainage, meteorological conditions and land use must be determined prior to analysis. Spring acquisition of polarimetric SAR data should produce better classification results for predicting soil drainage classes than late fall acquisition because weather conditions and land use would be less variable.

\section{Acknowledgments}

This project was funded by the Canadian Space Agency and Agriculture and Agri-Food Canada through a Government Related Initiatives Program (GRIP). We would like to 
acknowledge the contribution of partners to the project. We would also like to acknowledge the research assistants at Pedology and Agriculture Precision Laboratories for data collection.

\section{References}

Baronti S.; Del Frate F.; Ferrazzoli P.; Paloscia S.; Pampaloni P. \& Schiavon, G. (1995). SAR polarimetric features of agricultural areas. International Journal of Remote Sensing, Vol. 14, pp. 2639-2656

Bell, J.C.; Cunningham, R.L. \& Havens, M.W. (1992). Calibration and validation of a soillandscape model for predicting soil drainage class. Soil Sci. Soc. Am. J., Vol. 56, pp. 1860-1866

Bell, J.C.; Cunningham, R.L. \& Havens, M.W. (1994). Soil drainage class probability mapping using a soil-landscape model. Soil Sci. Soc. Am. J., Vol. 58, pp. 464-470

Cameron, W.L. \& Leung, L.K. (1990). Feature-motivated scattering matrix decomposition, Proc. IEEE Radar Conf., pp. 549-557, Arlington, VA, May 7-10, 1990

Campling, P.; Gobin, A. \& Feyen. J. (2002). Logistic modeling to spatially predict the probability of soil drainage classes. Soil Sci. Soc. Am. J., Vol. 66, pp. 1390-1401

Cialella, A.T.; Dubayah, R.; Lawrence, W. \& Levin, E. (1997). Predicting soil drainage class using remotely sensed and digital elevation data. Photogramm. Eng. Remote Sens., Vol. 63(2), pp. 171-178

Cloude, S.R. (1992). Uniqueness of Target Decomposition Theorems in Radar Polarimetry. Direct and Inverse Methods in Radar Polarimetry, Part 1, Boerner, W-M, (Ed.), pp. 267-296, Kluwer Academic Publishers, Dordrecht, Netherlands

Cloude, S.R. \& Pottier, E. (1996). A review of target decomposition theorems in radar polarimetry. IEEE Trans. GRS, Vol. 34(2), pp. 498-518, Mar. 1996

Cloude, S.R. \& Pottier, E. (1997). An entropy-based classification scheme for land applications of polarimetric SAR. IEEE Trans. GRS, Vol. 35(1), pp. 68-78

Dobson, M.C. \& Ulaby, F.T. (1986). Active microwave soil moisture research. IEEE Trans. GRS, Vol. GE-24(1), pp. 23-36

Freeman, A. \& Durden, S.L. (1998). A three-component scattering model for polarimetric SAR data, IEEE Trans. GRS, Vol. 36(3), pp. 963-973.

Fung, A.K. (1994). Microwave Scattering and Emission Models and their Applications, Artech House, Norwood, USA

Hajnsek, J. (2001). Inversion of surface parameters (soil moisture \& roughness) using polarimetric SAR. Doctoral Thesis, FSU, Jena, Germany, 2001 October 17 (ISSN 14348485 ISRN DLR-FB-2001-30)

Holm, W. \& Barnes, R.M. (1988). On radar polarization mixed target state decomposition techniques, IEEE Proceedings 1988 National Radar Conference, pp. 249-254, Ann Arbor, MI, USA

Huynen, J.R. (1965). Measurement of the target scattering matrix, Proc. IEEE, 53(8), pp. 936946 (also see: ibid, (1960), Radar target sorting based on polarization signature analysis, Lockheed, LMSD-288216, Sunnyvale, CA [AFCRC-TN-60-588, May 1960])

Kravchenko, A.N.; Bollero, G.A.; Omonode, R.A. \& Bullock, D.G. (2002). Quantitative mapping of soil drainage classes using topographical data and soil electrical conductivity. Soil Sci. Soc. Am. J., Vol. 66, pp. 235-243 
Krogager, E. (1992). Decomposition of the Sinclair Matrix into Fundamental Components with Application to High Resolution Radar Target Imaging. Direct and Inverse Methods in Radar Polarimetry, Part 2, Boerner, W-M., (Ed.), pp. 1459-1478, Kluwer Academic Publishers, Dordrecht, The Netherlands: (also see: ibid, 1993, "Aspects of Polarimetric Radar Target Imaging", Doctoral (Dr. Sci. Tech.) Thesis, Technical University of Denmark, Electromagnetics Institute, Lyngby, Denmark [check format]

Lee, J.S. (1986). Speckle suppression and analysis for synthetic aperture radar images. Optical Engineering, Vol. 25(81), pp. 636-643

Lee, K.-S.; Lee, G.B. \& Tyler, E.J. (1988). Determination of soil characteristics from Thematic Mapper data of a cropped organic-inorganic soil landscape. Soil Sci. Soc. Am. J., Vol. 52, pp. 1100-1104

Levine, E.R.; Knox, R.G. \& Lawrence W.T. (1994). Relationships between soil properties and vegetation at the Northern Experimental Forest, Howland, Maine. Remote Sens. Environ., Vol. 47, pp. 231-241

Liu, J.; Pattey, E.; Nolin, M.C.; Miller, J. \& Ka, O. (2008). Mapping within-field soil drainage using high resolution remote and proximal sensing data. Geoderma, Vol. 143, pp. 261-272

McNairn, H. \& Brisco, B. (2004). The application of C-band polarimetric SAR for agriculture: A review. Can. J. Remote Sens., Vol. 30(3), pp. 525-542

McNairn, H.; Duguay, C.; Brisco, B. \& Pultz, T.J. (2002). The effect of crop residue characteristics on polarimetric radar response. Remote Sensing of Environment, Vol. 80, pp. 309-320

Murnaghan, K. (2005). CV580 Quality report. Acquisition 04-03. Date: 9-Nov-2005. Line : 3002. Pass: 02. Location : Ste-Foy, Québec", 2p. 2005

Niang, M.; Bernier, M.; Nolin, M.C.; Ka, O. \& Liu, J. (2006). Approche quantitative pour la prédiction et la cartographie du drainage des sols par l'intégration de données ASTER et RADARSAT-1. Déc. 2006. Institut national de la recherche scientifique, centre Eau, Terre et Environnement, Québec, Canada. Rapport de recherche R-905, ISBN: 2-89146-530-X. $57 \mathrm{p}$

Niang, M.; Bernier, M.; Nolin, M.C.; Ka, O. \& Liu, J. (2007). Apport de l'imagerie radar multipolarisée et polarimétrique à la classification et à la cartographie du drainage des sols du bassin versant du Bras d'Henri. Mars 2007. Institut national de la recherche scientifique, centre Eau, Terre et Environnement, Québec, Canada. Rapport de recherche R-928, ISBN: 978-2-89146-540-3. 42 p

Nolin, M.C.; Lamontagne, L. \& Dubé, J.C. (1994). Cadre méthodologique d'une étude détaillée des sols et son application en terrain plat. Bulletin technique 1994-4F Direction générale de la recherche. AAC. Ste-Foy, Québec. CRTRB Contrib. No 93$41,78 \mathrm{p}$.

Jennifer, W. H., Rose, M., Cherie, S., David, K. S. \&Anthony, D. Mc. (2001). Soil drainage and its potential for influencing wildfires in Alaska. Studies by U.S. Geological Survey in Alaska, U.S. Geological Survey Professional, paper 1678, pp. 139-144.

Smith, A.M.; Eddy, P.R.; Bugden-Storie, J.; Pattey, E.; McNairn, H.; Nolin, M.; Perron, I.; Hinther, M.; Miller, J. \& Haboudane, D. (2006). Multi-polarized radar for delineating within-field variability in corn and wheat, Canadian Journal of Remote Sensing, Vol. 45 (4), pp. 300-313 
Smith, A.M.; Eddy P.; Bugden-Storie J.; Pattey E.; McNairn H.; Nolin, M.C.; Miller J. \& Haboudane, D. (2003). Delineating within-field management zones using multitemporal, multi-polarized airborne SAR imagery. Proceedings $25^{\text {th }}$ Canadian Remote Sensing Conference, Montreal, Quebec, October 2003

Touzi, R. \& Charbonneau, F.J. (2004). PWS: A friendly and effective tool for polarimetric image analysis. Can. J. Remote Sens., Vol. 30(3), pp. 566-571

Ulaby, F.T.; Moore, R.K. \& Fung, A.K. (1986). Microwave Remote Sensing, Active and Passive, Volume Scattering and Emission Theory - Advanced Systems and Applications 3, Artech, Dedham, MA

van der Sanden, J.J. (2004). Anticipated applications potential of RADARSAT-2 data. Can. J. Remote Sensing, Vol. 30(3), pp. 369-379

van Zyl, J.J. (1989). Unsupervised classification of scattering behavior using radar polarimetry data. IEEE Trans. GRS, Vol. GE-27, pp. 36-45 


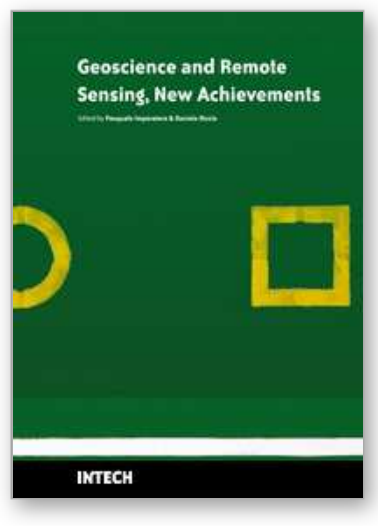

\author{
Geoscience and Remote Sensing New Achievements \\ Edited by Pasquale Imperatore and Daniele Riccio
}

ISBN 978-953-7619-97-8

Hard cover, 508 pages

Publisher InTech

Published online 01, February, 2010

Published in print edition February, 2010

Our planet is nowadays continuously monitored by powerful remote sensors operating in wide portions of the electromagnetic spectrum. Our capability of acquiring detailed information on the environment has been revolutionized by revealing its inner structure, morphology and dynamical changes. The way we now observe and study the evolution of the Earth's status has even radically influenced our perception and conception of the world we live in. The aim of this book is to bring together contributions from experts to present new research results and prospects of the future developments in the area of geosciences and remote sensing; emerging research directions are discussed. The volume consists of twenty-six chapters, encompassing both theoretical aspects and application-oriented studies. An unfolding perspective on various current trends in this extremely rich area is offered. The book chapters can be categorized along different perspectives, among others, use of active or passive sensors, employed technologies and configurations, considered scenario on the Earth, scientific research area involved in the studies.

\title{
How to reference
}

In order to correctly reference this scholarly work, feel free to copy and paste the following:

Mohamed A. Niang, Michel C. Nolin and Monique Bernier (2010). Potential of C-Band Multi-polarized and Polarimetric SAR Data for Soil Drainage Classification and Mapping, Geoscience and Remote Sensing New Achievements, Pasquale Imperatore and Daniele Riccio (Ed.), ISBN: 978-953-7619-97-8, InTech, Available from: http://www.intechopen.com/books/geoscience-and-remote-sensing-new-achievements/potential-of-cband-multi-polarized-and-polarimetric-sar-data-for-soil-drainage-classification-and-m

\section{INTECH}

open science | open minds

\section{InTech Europe}

University Campus STeP Ri

Slavka Krautzeka 83/A

51000 Rijeka, Croatia

Phone: +385 (51) 770447

Fax: +385 (51) 686166

www.intechopen.com

\section{InTech China}

Unit 405, Office Block, Hotel Equatorial Shanghai

No.65, Yan An Road (West), Shanghai, 200040, China 中国上海市延安西路65号上海国际贵都大饭店办公楼 405 单元

Phone: +86-21-62489820

Fax: $+86-21-62489821$ 
(C) 2010 The Author(s). Licensee IntechOpen. This chapter is distributed under the terms of the Creative Commons Attribution-NonCommercialShareAlike-3.0 License, which permits use, distribution and reproduction for non-commercial purposes, provided the original is properly cited and derivative works building on this content are distributed under the same license. 